\title{
Influence of Treated Palm Oil Mill Effluent Sludge on Maize (Zea mays) Growth Performance and Gas Exchange
}

(Pengaruh Enapcemar Sawit Terawat pada Jagung (Zea mays) untuk Prestasi Pertumbuhan dan Pertukaran Gas)

\author{
MOHD NIZAR, K., ISHARUdin, M.I.* ABD JAMIL, Z. \& HAZANDY, A.H.
}

\begin{abstract}
The presence of abundant oil palm residues in Malaysia prompted the need to utilize this waste to avoid environmental pollution. This waste was abundant at the oil palm mill and accounted for almost $50 \%$ of production. The study was conducted to determine the morphological effect of Palm Oil Mill Effluent (POME) sludge on the maize growth performance and gas exchange. Physicochemical, growth morphology and gas exchange was measured after treated with POME sludge from different treatment pond systems: Mixing, anaerobic, facultative, algae and dumping. The results indicated the $\mathrm{pH}, \mathrm{C}$, and CEC of mixing the < anaerobic < facultative $<$ algae $<$ dumping ponds. There was a significant presence of macronutrient $(\mathrm{N}, \mathrm{Mg}, \mathrm{Ca}, \mathrm{Fe}, \mathrm{S})$ in the treated POME sludge, contrary to the presence of heavy metal $(\mathrm{Cd}, \mathrm{Cu}, \mathrm{Ni}$ and $\mathrm{Pb}$ ) elements which were not significantly different in all the treatments and lower than WHO/FAO standard. Root Shoot Ratio (RSR) and Specific Leaf Area (SLA) indicated significant difference in biomass accumulation and yield compared to the control. The gas exchange variable was a significant difference on stomata conductivity (Gs) and transpiration rate (E). However, the POME sludge from the facultative, algae and dumping ponds showed positive correlations between net photosynthesis, stomata conductivity and transpiration rate. Indeed, the increased transpiration rate $(E)$ was correlated with stomata conductance (Gs) after treatment with anaerobic, facultative, algae and dumping ponds. In conclusion, the POME sludge amendment was able to increase the maize biomass and yield.
\end{abstract}

Keywords: Gas exchange; growth performance; POME sludge amendment

ABSTRAK

Kehadiran sisa kelapa sawit banyak terdapat di Malaysia mendorong keperluan untuk menggunakan sisa ini untuk mengatasi pencemaran alam sekitar. Sisa yang banyak dihasilkan dari kilang kelapa sawit efluen (POME) enapcemar dan menyumbang hampir 50\% daripada pengeluaran. Kajian ini telah dijalankan untuk menentukan kesan morfologi POME kumbahan dan gas pertukaran pada prestasi pertumbuhan jagung. Fizikokimia, morfologi pertumbuhan dan tindak balas pertukaran gas untuk jagung (Zea mays) ditanam dengan campuran tanah dan enapcemar POME daripada sistem rawatan kolam berbeza iaitu (campuran, anaerobik, fakultatif, alga dan lambakan). Keputusan menunjukkan bahawa $\mathrm{pH}, \mathrm{C}$, dan CEC pada kolam campuran <anaerobik <fakultatif <alga <lambakan. Terdapat makronutrien iaitu $(\mathrm{N}, \mathrm{Mg}, \mathrm{Ca}, \mathrm{Fe}, \mathrm{S})$ dalam enapcemar POME yang dirawat. Bertentangan dengan kehadiran logam berat $(\mathrm{Cd}, \mathrm{Cu}, \mathrm{Ni}$ dan $\mathrm{Pb}$ ) unsur yang tidak berbeza secara ketara dalam semua rawatan dan lebih rendah daripada piawai WHO/FAO. Nisbah akar pucuk (RSR) dan khusus kawasan daun (SLA) telah menunjukkan perbezaan yang ketara dalam pengumpulan biojisim dan hasil berbanding dengan kawalan. Pertukaran gas parameter tidak jauh berbeza antara rawatan kecuali stomata kekonduksian (Gs) dan kadar transpirasi (E). Walau bagaimanapun, enapcemar POME daripada fakultatif, alga dan lambakan kolam telah menunjukkan korelasi positif antara fotosintesis bersih, stomata kekonduksian dan kadar transpirasi. Malah, peningkatan kadar transpirasi (E) telah dikaitkan dengan stomata kealiran (Gs) selepas dirawat dengan anaerobik, fakultatif, alga dan lambakankolam. Kesimpulannya, enap cemar pindaan POME dapat meningkatkan biojisim dan hasil jagung.

Kata kunci: Pertukaran gas; POME enapcemar pindaan; prestasi pertumbuhan

\section{INTRODUCTION}

The management of organic matter is an important aspect in sustaining the productivity of soil in the tropics. In general, Malaysia has produced about half the organic waste of the palm oil industry and it has not been fully utilized. Embrandiri et al. (2013) reported that palm oil effluent, palm kernel cake, decanter cake, empty fruit bunch and palm kernel shell have the potential to be used as an organic amendment to the soil. Many studies have indicated that plant production has benefited from the application of organic matter (Agrawal et al. 2010). Some of the studies used decanter cake as an organic amendment in Okra (Embrandiri et al. 2013), tannery sludge with capsicum plants (Silva et al. 2010) and cowpea (Silva et al. 2013). However fewer studies have reported the use of POME sludge on maize growth 
performance and gas exchange. Khairuddin et al. (2016) reported that the treated POME sludge consisted of a balance of $\mathrm{C}, \mathrm{N}$ and macronutrients. Mostly, these elements were required to improve crop productivity. Moreover, the heavy metal content was in accordance with WHO/FAO safety standards for human consumption. The effect of POME sludge on the morphology, maize growth variables and gas exchange are important to explore. Morphological analysis showed that the organic amendment positively affects plant growth. Organic amendment from palm oil was a suitable substitute for inorganic fertilizers (Embrandiri et al. 2013). The positive effect on the crop growth was observed due to high nutrient content in the organic matter. Hazandy et al. (2011) reported that the measurement of net photosynthesis $\left(A_{\text {net }}\right)$, stomata conductance $\left(G_{s}\right)$ internal $\mathrm{CO}_{2}$ concentration $\left(\mathrm{C}_{\mathrm{i}}\right)$, transpiration rate $\left(\mathrm{E}_{\mathrm{L}}\right)$ and air vapor pressure deficit (D) were used to measure the response of plants to their environment. All the measurements directly influence the physical growth of maize. Therefore, this research aimed to utilize the POME sludge for productivity improvement and soil fertility, plant morphology, growth variable and gas exchange. The POME sludge became the alternative nutrients supply for the soil, diminishing and utilizing waste materials through beneficial usage.

\section{MATERIALS AND METHODS}

\section{STUDY SITE}

The experimental site was located at the Research Farm of the Universiti Teknologi MARA Pahang, Campus Jengka, Pahang, Malaysia $\left(3.7562{ }^{\circ} \mathrm{N}, 102.5611^{\circ} \mathrm{E}\right)$ during the period, February 2015 to June 2016. Generally, this area is a tropical climate with average temperature of $31^{\circ} \mathrm{C}$, rainfall of $2300 \mathrm{~mm}$ annually and relative humidity of $60-80 \%$. The POME samples were taken from the palm oil mill, Felda Jengka 8, Bandar Tun Abdul Razak Jengka, Pahang, Malaysia, from a system of different treatment ponds (mixing, anaerobic, facultative, algae and dumping). The POME treatment systems had undergone different Hydraulic Retention Time (HRT) processes: cooling ponds (1 day), mixing ponds (2 days), anaerobic ponds (45 days), facultative ponds (20 days) and algae ponds (7 days). According to Khairuddin et al. (2016), millions of tonnes of sludge were pumped into the dumping ponds for maintenance processes and for stabilization of the POME sludge before being applied to the soil.

\section{EXPERIMENTAL DETAILS}

The experiments were arranged in a randomized complete blocks design (RCBD). The maize was planted in a polybag of $16 \times 20 \mathrm{~cm}$. In this study, Zea mays L. (Hibrimas variety), was used as a test crop for growth and physiological characteristics. POME sludge from the different treatments such as mixing ponds (MP), anaerobic ponds (ANP), facultative ponds (FP), algae ponds (ALP) and dumping ponds (DP) were used as soil amendments. The Rasau soil series (Entisols) was chosen due to its lack of organic matter, $\mathrm{pH}$ and CEC.

\section{SOIL PHYSICOCHEMICAL CHARACTERISTICS}

The soil samples of each treatment were collected, then crushed, air dried and sieved into $2 \mathrm{~mm}$ size. POME sludge treatment samples were digested and analysed for physiochemical properties. The $\mathrm{pH}(\mathrm{pH}$ meter-Mettler Toledo S20-K), CNS analyzer (Model 2400 Perkin Elmer), moisture content, nutrient and heavy metal element ICP-OES (Optima 5300 DV-Perkin Elmer) were used for measurement of the soil's effect. The POME sludge was prepared in accordance with standard methods following the procedures of the wastewater (APHA 2005) for the physicochemical characteristic analysis.

\section{MORPHOLOGY AND GROWTH VARIABLES}

Morphology and growth variables were observed and measured such as plant height, plant diameter, leaf number, leaf area, root density, ear length, ear diameter, ear biomass, leaf biomass, shoot biomass and root biomass. The shoot, root and leaf parts were placed in the oven at $80^{\circ} \mathrm{C}$ until a constant weight was achieved for biomass determination. The maize parts were then weighed separately (leaf, shoot and root) for biomass weight. The growth parameter was then statistically correlated with the selected morphological characteristics (leaf area, leaf biomass, shoot biomass and total biomass). In accordance with Hunt (2002), the growth parameter was formulated by correction of the leaf area ratio (LAR) (1), specific leaf area (SLA) (2), leaf weight ratio (LWR) (3) and root-shoot ratio (RSR) (4). Below are the details:

$$
\begin{aligned}
& \operatorname{LAR}\left(\mathrm{cm}^{2} \mathrm{~g}^{-1}\right)=\frac{\text { Leaf area }}{\text { Total biomass }} \\
& \text { SLA }\left(\mathrm{cm}^{2} \mathrm{~g}^{-1}\right)=\frac{\text { Leaf area }}{\text { Leaf biomass }} \\
& \operatorname{LWR}\left(\mathrm{cm}^{2} \mathrm{~g}^{-1}\right)=\frac{\text { Leaf biomass }}{\text { Total biomass }} \\
& \text { SLA }\left(\mathrm{cm}^{2} \mathrm{~g}^{-1}\right)=\underline{\text { Root biomass }} \\
& \text { Shoot biomass }
\end{aligned}
$$

\section{GAS EXCHANGE PARAMETER}

The leaves were selected from each POME sludge treatment and maize samples. The net photosynthesis $\left(\mathrm{A}_{\text {net }}\right)$, stomata conductance $\left(\mathrm{G}_{\mathrm{s}}\right)$, internal $\mathrm{CO}_{2}$ concentration $\left(\mathrm{C}_{\mathrm{i}}\right)$, transpiration rate $\left(\mathrm{E}_{\mathrm{L}}\right)$ and air vapor pressure deficit (D) were measured for each sample. The measurement was effected using a portable photosynthesis meter (LiCOR, Inc., Lincoln, Nebraska, USA) and the data recorded during the period from 8.00 am to $12.30 \mathrm{pm}$. 


\section{STATISTICAL ANALYSIS}

Statistical analyses were conducted using the SAS 9.4 statistical package (SAS 2007). Analysis of variance (ANOVA) was conducted to test the treatments effect while means separation was effected using the Tukey test at $p<0.05$.

\section{RESULTS AND DISCUSSION}

\section{PHYSICOCHEMICAL PROPERTIES OF POME SLUDGE}

Generally, the POME sludge samples were blackish, textured and smelly (Khairuddin et al. 2016). However, POME sludge from the mixing ponds and cooling ponds was oily and dark yellowish in colour. Furthermore, both of them were less moist and the presence of a dark brownish colour was interpreted as typical of anaerobic, facultative and algae ponds. Nevertheless, sludge from the dumping ponds showed a blackish colour and was less smelly compared to the other sludge. Figure 1(a) shows the effect of POME sludge treatments on soil $\mathrm{pH}$ after the application of treatments. The DP was found to be significantly different compared to the other treatments. There was no significant difference between ALP and FP. The soil $\mathrm{pH}$ of DP recorded the highest mean value at 8.31 compared to the other treatments. This $\mathrm{pH}$ value being alkaline was suitable for plant growth such as cabbage, cauliflower, and thyme (Tisdale et al. 1993). At this $\mathrm{pH}$ level, other micronutrients present, such as iron, manganese and phosphorus, were less available (Jensen 2010). The lowest soil pH was observed in the control treatment at 3.42. The organic amendment application was able to improve the soil $\mathrm{pH}$ : as the organic matter increased, the soil recovered its natural buffer capacity, resulting in an increase in $\mathrm{pH}$ of the acid soils. However, the DP was recommended as stable and safe to be used as an organic amendment. The soil $\mathrm{pH}$ of MP was measured at 4.12 while ANP was 5.2, which were acidic and not suitable for maize growth. Maize has poor tolerance of low $(<5.5) \mathrm{pH}$ soils when aluminium toxicity reduces root development and manganese toxicity also reduces plant development (OGTR 2008). The pH of ALP and FP was observed at 7.08 and 6.4, suggesting that most of the nutrients were available for plant uptake (Bruulsema et al. 2008). The effect of treatments on total carbon in soil after the application of various treatments is shown in Figure 1(b). There was a significant difference $(p \leq 0.05)$ in DP compared to ANP, ALP, MP and the control. The MP and FP showed no significant differences. The DP treatment showed the highest soil total C (20.8\%) compared to the other treatments, while the lowest soil total $\mathrm{C}$ was observed in MP at $4.05 \%$. As shown in Figure 1, MP had a lower composition of organic carbon that could be attributed to the POME sludge decomposition process that was still occurring due to the activity of the micro-organisms and correlated to the hydraulic retention time (HRT) of wastewater treatment practices (Badiei et al. 2011). The hydraulic retention time (HRT) in each wastewater treatment pond indicated that the different level of nitrification capability processes occurring, resulted in differences in the efficiency levels and economic perspectives (David \& King 2005). According to Dungait (2012), the availability of organic carbon in soil acted as the main source of energy for soil microorganisms. Moreover, an increase in soil organic matter affected the total carbon, leading to greater biological diversity in the soil (Rumpel et al. 2015). Application of organic amendment in soil might provide organic carbon as the major soil nutrients, such as nitrogen, phosphorus, and potassium, providing a significant increase in the sandy loam soil (Zhong et al. 2010). Subsequently, the results of this study also showed that the application of organic amendment significantly improved the soil organic carbon content in the Rasau soil series.

Nitrogen is important for crop growth and development. Figure 1(c) shows that there was a significant difference $(p \leq 0.05)$ in MP compared to the other treatments. However, the DP treatment (1.82\%) showed the lowest soil total nitrogen compared to the MP treatment (4.24\%). The nitrogen intake is an essential nutrient for cell growth (Ali Hudin et al. 2012). Ryals et al. (2014) stated that nitrogen was produced from the decomposition process. During the breakdown of the organic matter, any excess nutrients $(\mathrm{N}, \mathrm{P}$, and $\mathrm{S})$ were released into the soil in the forms that could be used by the plants. Figure 1(d) shows that in the effect of treatment on cation exchange capacity (CEC), there were significant differences $(p \leq 0.05)$ in DP, ALP and FP compared to the other treatments. The DP treatment showed the highest mean value of $0.30 \mathrm{meq} / 100$ g compared to the other treatments. There were significant differences between ANP, MP and the control. A high CEC value indicated that soil has a greater capacity to hold cations. The use of organic amendments was associated with desirable soil properties including high water-holding capacity and CEC and lower bulk density, which can foster the beneficial micro-organisms (Drinkwater et al. 1998). As a consequence of organic amendment applications, the organic carbon stock and CEC was increased. A high CEC value would allow some essential nutrients to be retained, making them available for crop production.

The measurement of the heavy metal properties of the POME sludge system shown in Table 2, exhibits the influence of different treatment systems on POME sludge. The POME sludge from FP and ALP indicated the highest values of Copper $(60.85 \mathrm{mg} / \mathrm{kg})$, Nickel $(11.86 \mathrm{mg} / \mathrm{kg})$, Chromium (31.17 mg/kg) and Manganese (473.63 mg/kg). However, samples from the dumping ponds showed that a low amount of Plumbum $(0.39 \mathrm{mg} / \mathrm{kg})$ was observed. Furthermore, the value of heavy metal in each treatment pond system was shown to be below the WHO-ML standard. These demonstrated that the POME sludge was safe to use for application on arable land.

Based on Table 1, Phosphorus was significantly higher $(p<0.05)$ in the DP $(8.60 \mathrm{mg} \mathrm{kg}-1)$ and ALP $(8.61$ $\mathrm{mg} \mathrm{kg}^{-1}$ ) compared to the other treatments. There was no 

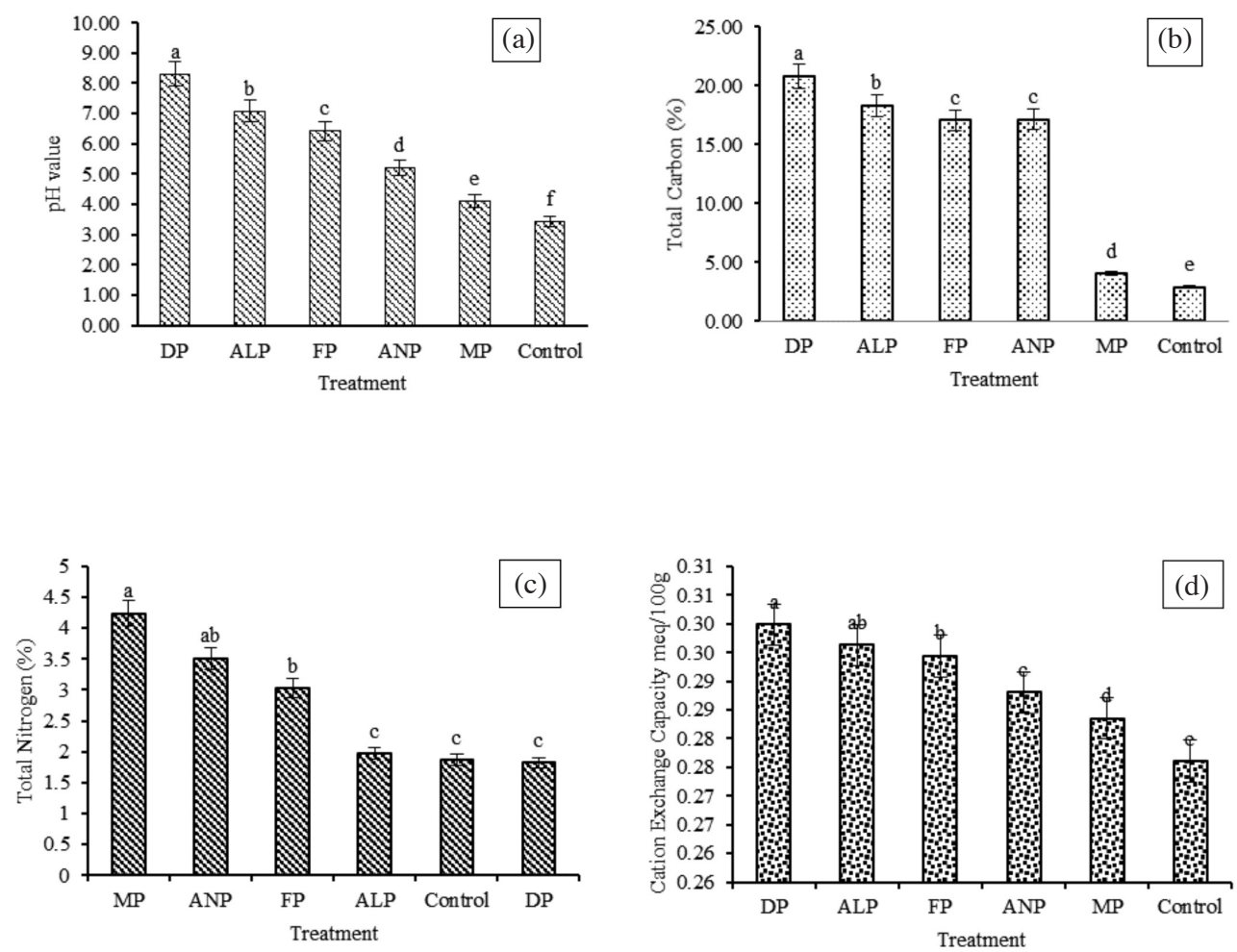

(Means with the same letter are not significantly different at $p \leq 0.05$, according to Tukey)

FIGURE 1. Effect of Treatments on the $\mathrm{pH}$ value, total carbon, total nitrogen and CEC of soil

significant difference between DP and ALP treatments. In this study, the DP treatment was shown to have a higher amount of phosphorous $(\mathrm{P})$ than the amount that could be utilized and absorbed by the roots for growth. According to Taiz and Zeiger (1991), P plays an important role in ATP build-up in plants. Kulhman et al. (1990) reported that $\mathrm{P}$ was an essential element in soil, forming inorganic phosphate that becomes part of the soil organic matter. In addition, the POME sludge waste resulted in significantly higher $(p<0.05)$ potassium in the DP $\left(16.00 \mathrm{mg} \mathrm{kg}^{-1}\right)$ than the control $\left(5.71 \mathrm{mg} \mathrm{kg}^{-1}\right)$. Potassium was considered an immobile nutrient in the soil. However, CEC was increased therefore Potassium can be mobilized in the POME sludge. The concentration of Magnesium was the highest in the DP $\left(5.33 \mathrm{mg} \mathrm{kg}^{-1}\right)$ followed by ALP $\left(4.78 \mathrm{mg} \mathrm{kg}^{-1}\right)$. Moreover, Calcium concentration was higher in DP $\left(26.29 \mathrm{mg} \mathrm{kg}^{-1}\right)$ than the control $\left(18.17 \mathrm{mg} \mathrm{kg}^{-1}\right)$ and could be due to the higher $\mathrm{Ca}$ content of raw POME sludge from the dumping pond, than from the others. The presence of Calcium and Magnesium showed that this can affect cation exchange capacity and help to promote favourable soil structure. Silva et al. (2010) reported that the chlorophyll formation in the leaf is dependent on $\mathrm{Mg}$ and $\mathrm{Ca}$.

There were significant $(p<0.05)$ differences in the Sulphur content in the DP and ANP treatments compared to the other treatments. The DP $(4.12 \%)$ treatment showed the highest $\mathrm{S}$ content. According to Sharma and Singh (2001), S content was important in plant tissues and also helps in maintaining water equilibrium in the plant. Generally, the POME sludge had significantly increased the total macro-nutrient contents of DP, ALP and FP compared to the control.

TABLE 1. Nutrient properties of POME sludge in different treatment systems

\begin{tabular}{lcccccc}
\hline \multirow{2}{*}{ Parameter } & \multicolumn{5}{c}{ Treatment } \\
\cline { 2 - 7 } & DP & ALP & FP & ANP & MP & Control \\
\hline Potassium $\left(\mathrm{mg} / \mathrm{kg}^{-1}\right)$ & $16.00 \mathrm{a}$ & $14.66 \mathrm{ab}$ & $14.65 \mathrm{ab}$ & $10.87 \mathrm{bc}$ & $9.35 \mathrm{~cd}$ & $5.71 \mathrm{~d}$ \\
Magnesium $\left(\mathrm{mg} / \mathrm{kg}^{-1}\right)$ & $5.329 \mathrm{a}$ & $5.33 \mathrm{a}$ & $4.78 \mathrm{~b}$ & $3.50 \mathrm{c}$ & $2.12 \mathrm{~d}$ & $0.40 \mathrm{e}$ \\
Calcium $\left(\mathrm{mg} / \mathrm{kg}^{-1}\right)$ & $26.30 \mathrm{a}$ & $24.10 \mathrm{~b}$ & $23.7 \mathrm{bc}$ & $22.57 \mathrm{~cd}$ & $21.47 \mathrm{~d}$ & $18.17 \mathrm{e}$ \\
Phosphorus $\left(\mathrm{mg} / \mathrm{kg}^{-1}\right)$ & $8.603 \mathrm{a}$ & $8.61 \mathrm{a}$ & $6.98 \mathrm{~b}$ & $5.10 \mathrm{c}$ & $4.59 \mathrm{~cd}$ & $2.85 \mathrm{de}$ \\
Ferum $\left(\mathrm{mg} / \mathrm{kg}^{-1}\right)$ & $71.34 \mathrm{a}$ & $65.57 \mathrm{~b}$ & $53.94 \mathrm{c}$ & $45.69 \mathrm{~d}$ & $42.06 \mathrm{e}$ & $39.11 \mathrm{f}$ \\
Sulphur $(\%)$ & $4.12 \mathrm{a}$ & $2.61 \mathrm{~b}$ & $1.85 \mathrm{c}$ & $3.86 \mathrm{a}$ & $0.13 \mathrm{~d}$ & $0.08 \mathrm{~d}$ \\
\hline
\end{tabular}

Means with the same letter are not significantly different at $p \leq 0.05$, according to Tukey 
Table 2 shows the changes in Copper content for the various treatments. There were significant decreases $(p<0.05)$ of Copper in the DP $\left(0.44 \mathrm{mg} \mathrm{kg}^{-1}\right)$, control $(0.62$ $\left.\mathrm{mg} \mathrm{kg}{ }^{-1}\right)$ and MP $\left(0.79 \mathrm{mg} \mathrm{kg}^{-1}\right)$ treatments. Meanwhile, there was insignificant difference of Cadmium in each treatment. Indeed, Plumbum and Nickel content was significantly $(p<0.05)$ different compared to the DP and control. Khairuddin et al. (2016) reported that the concentrations of $\mathrm{Cu}, \mathrm{Cd}, \mathrm{Pb}$ and $\mathrm{Ni}$ were safe according to WHO/FAO standards for human consumption. Heavy metals can affect the growth, morphology and metabolism of micro-organisms in bulk soils, through functional disturbance, protein denaturation or the destruction of the integrity of cell membranes (Leita et al. 1995). In addition, organic matter was also supplied as organic chemicals to the soil solution, serving as chelates and as metal availability to plants (McCauley et al. 2009). The heavy metal adsorption into soil constituents declined with the decrease in organic matter content in soils and dissolved organic matter could increase the mobility and uptake of heavy metals to the plant roots. Zeng et al.(2011) estimated that $\mathrm{Cd}, \mathrm{Pb}$ and $\mathrm{Zn}$ content in heavy metal contaminated soils were positively correlated with the organic matter content in soils.

\section{GROWTH AND MORPHOLOGICAL CHARACTHERISTIC}

Table 3 shows the results of height, diameter, ears diameter, ears length, ears number, leaf number, leaf area, leaf biomass, leave area meter, stand biomass and root ratio of maize for control (without treatment), MP, ANP, FP, ALP and DP. In this study, maize growth performance was identified through the production of plant morphology and biomass. There was a significant difference in plant height for ANP, FP, ALP and DP treatments compared to control and for diameter measurement there was significant difference in the ALP compared to FP, ANP, MP and control treatments. There was no significant difference between ALP and DP in the diameter of the plant. Moreover, the maximum to minimum heights were from DP $>$ FP $>$ ALP $>$ ANP $>$ MP $>$ control, respectively. Among the treatments of POME sludge application, the DP treatment was significantly different compared to ANP, MP and Control. There was no significant difference in leaf number for DP, ALP and FP treatments. There was a significant difference in leaf area for the DP treatment compared to the other treatments. These results indicated that composted POME sludge was able to promote a beneficial effect on the height, diameter, leaf number and leaf area. According to Gupta and Sinha (2006) and Silva et al. (2010), sludge composts mainly contributed $\mathrm{N}$ and $\mathrm{P}$ as nutrients for plant growth. The composition of the soil rich in nitrogen was able to promote the growth and size of the leaves. In this experiment, the ear length, diameter and number were measured as yield parameters. However, ANP $(34.98 \mathrm{~mm})$ treatment was identified as having the highest yield among the other treatments. There was a significant difference in ear diameter for the ANP compared to DP, MP and Control treatments.

TABLE 2. Heavy metal properties of POME sludge in different treatment systems

\begin{tabular}{lcccccc}
\hline \multirow{2}{*}{ Parameter } & \multicolumn{7}{c}{ Treatment } \\
\cline { 2 - 7 } & DP & ALP & FP & ANP & MP & Control \\
\hline Nickel $\left(\mathrm{mg} / \mathrm{kg}^{-1}\right)$ & $0.18 \mathrm{~b}$ & $0.17 \mathrm{~b}$ & $0.17 \mathrm{~b}$ & $0.18 \mathrm{~b}$ & $0.18 \mathrm{~b}$ & $0.35 \mathrm{a}$ \\
Copper $\left(\mathrm{mg} / \mathrm{kg}^{-1}\right)$ & $0.44 \mathrm{c}$ & $0.47 \mathrm{c}$ & $0.43 \mathrm{c}$ & $0.66 \mathrm{~b}$ & $0.79 \mathrm{a}$ & $0.62 \mathrm{~b}$ \\
Plumbum $\left(\mathrm{mg} / \mathrm{kg}^{-1}\right)$ & $0.33 \mathrm{~b}$ & $0.34 \mathrm{~b}$ & $0.29 \mathrm{~b}$ & $0.35 \mathrm{~b}$ & $0.31 \mathrm{~b}$ & $0.51 \mathrm{a}$ \\
Cadmium $\left(\mathrm{mg} / \mathrm{kg}^{-1}\right)$ & $0.01 \mathrm{a}$ & $0.01 \mathrm{a}$ & $0.01 \mathrm{a}$ & $0.01 \mathrm{a}$ & $0.01 \mathrm{a}$ & $0.01 \mathrm{a}$ \\
\hline
\end{tabular}

Means with the same letter are not significantly different at $p \leq 0.05$, according to Tukey

TABLE 3. Growth morphology of maize (Zea mays) grown in different POME sludges

\begin{tabular}{lcccccc}
\hline Parameter & \multicolumn{5}{c}{ Treatment } \\
\cline { 2 - 7 } & Control & MP & ANP & FP & ALP & DP \\
\hline Plant Height $\left(\mathrm{cm} \mathrm{plant}^{-1}\right)$ & $63.79 \mathrm{c}$ & $78.17 \mathrm{~b}$ & $89.93 \mathrm{ab}$ & $94.96 \mathrm{a}$ & $92.02 \mathrm{a}$ & $96.533 \mathrm{a}$ \\
Stem diameter $\left(\mathrm{mm} \mathrm{plant}^{-1}\right)$ & $20.94 \mathrm{~d}$ & $21.75 \mathrm{~d}$ & $24.91 \mathrm{c}$ & $26.27 \mathrm{cb}$ & $28.64 \mathrm{a}$ & $27.87 \mathrm{ab}$ \\
Ear Diameter $(\mathrm{mm})$ & $17.023 \mathrm{~b}$ & $30.07 \mathrm{~b}$ & $34.98 \mathrm{a}$ & $32.82 \mathrm{ab}$ & $32.17 \mathrm{ab}$ & $33.76 \mathrm{~b}$ \\
Ear Length $(\mathrm{mm})$ & $3.38 \mathrm{c}$ & $8.41 \mathrm{bc}$ & $9.91 \mathrm{ab}$ & $14.91 \mathrm{a}$ & $13.06 \mathrm{ab}$ & $15.13 \mathrm{a}$ \\
Ear Number & $0.75 \mathrm{~d}$ & $1.25 \mathrm{~cd}$ & $1.50 \mathrm{~cd}$ & $2.25 \mathrm{a}$ & $2.0 \mathrm{ab}$ & $2.375 \mathrm{a}$ \\
Leaf Number & $7.63 \mathrm{~d}$ & $8.37 \mathrm{~cd}$ & $10.12 \mathrm{bc}$ & $10.87 \mathrm{ab}$ & $11.50 \mathrm{ab}$ & $12.75 \mathrm{a}$ \\
Leave Area $\left(\mathrm{cm}^{2}\right.$ plant $\left.^{-1}\right)$ & $1559.50 \mathrm{~d}$ & $2492.20 \mathrm{~cd}$ & $3115.80 \mathrm{bc}$ & $4178.50 \mathrm{~b}$ & $4403.1 \mathrm{~b}$ & $6060.30 \mathrm{a}$ \\
Leaf Biomass $\left(\mathrm{g} \mathrm{plant}^{-1}\right)$ & $0.05 \mathrm{c}$ & $0.08 \mathrm{~b}$ & $0.08 \mathrm{ab}$ & $0.08 \mathrm{ab}$ & $0.11 \mathrm{a}$ & $0.09 \mathrm{ab}$ \\
Shoot Biomass $\left(\mathrm{g} \mathrm{plant}^{-1}\right)$ & $0.06 \mathrm{c}$ & $0.15 \mathrm{bc}$ & $0.19 \mathrm{~b}$ & $0.23 \mathrm{~b}$ & $0.27 \mathrm{ab}$ & $0.38 \mathrm{a}$ \\
Root Biomass $\left(\mathrm{g} \mathrm{plant}^{-1}\right)$ & $0.008 \mathrm{c}$ & $0.01 \mathrm{bc}$ & $0.01 \mathrm{bc}$ & $0.02 \mathrm{~b}$ & $0.02 \mathrm{~b}$ & $0.03 \mathrm{a}$ \\
Total Biomass $\left(\mathrm{g} \mathrm{plant}^{-1}\right)$ & $0.14 \mathrm{c}$ & $0.25 \mathrm{bc}$ & $0.30 \mathrm{abc}$ & $0.37 \mathrm{ab}$ & $0.35 \mathrm{ab}$ & $0.47 \mathrm{a}$ \\
\hline
\end{tabular}

Means with the same letter are not significantly different at $p \leq 0.05$, according to Tukey 
There was no significant difference between ANP, FP and ALP treatments. The application of POME sludge proved that the presence of additional organic matter in the soil improved the plant growth with regard to plant height, stem diameter, ear diameter and leaf area.

Leaf, shoot and root biomass was reflected in the overall maize growth performance. The growth performance was measured based on the plant dry weight. There was a significant difference in leaf, shoot and root biomass for each treatment and the best response was achieved in DP and ALP treatments. According to Birch et al. (2003), the growing maize had a high demand for nutrients, especially nitrogen $(\mathrm{N})$, phosphorus $(\mathrm{P})$ and potassium $(\mathrm{K})$. The soil fertility status was increased by adding organic amendments, affecting the maize growth rate in the production of plant height, leaf area, and root mass. Once the soil fertility reaches appropriate medium for crop growth, the plant growth performance will improve (Kuzyakov \& Cheng 2001).

The data recorded the selected physiological characteristics of maize as shown in Table 3 . The highest total biomass values were in DP $\left(0.47 \mathrm{~g} \mathrm{plant}^{-1}\right)$, ALP $\left(0.35 \mathrm{~g} \mathrm{plant}^{-1}\right)$ and FP $\left(0.37 \mathrm{~g} \mathrm{plant}^{-1}\right)$ treatments, respectively. The biomass was used to monitor the effects of various environment variables. There was no significant difference in Leaf Area Ratio (LAR) for all treatments, as shown in Table 4. The increase in leaf size was an attempt to maximize the plant economy in the acquisition of resources which are needed for growth and development (Amanullah et al. 2007). LAR indicates that there are more cells, the leaf area increases, the rate of photosynthesis becomes faster, leading to increased dry matter production. In this study, Leaf Weight Ratio (LWR) was insignificantly different across all the treatments.
There were significant differences in Root Shoot Ratio (RSR) between the DP $\left(0.22 \mathrm{~g} \mathrm{~g}^{-1}\right)$ and control $\left(0.03 \mathrm{~g} \mathrm{~g}^{-1}\right)$ treatments.

Root Shoot Ratio (RSR), denoting the apportionment of photosynthesis between the above and below ground plant parts, showed significant results between treatments. According to Brouwer (1983), the root system allows a plant to absorb water and nutrients from the surrounding soil, and this promotes a healthy root system. An increase in the root shoot ratio could be an indication of a healthier plant provided the increase originated from a greater root size. Specific Leaf Area (SLA) for maize plants was the highest in DP application $\left(688.70 \mathrm{~cm}^{2} \mathrm{~g}^{-1}\right)$ and not significantly different with ALP, FP, ANP and MP treatments, though all treatments were significantly different when compared to the Control $\left(324.9 \mathrm{~cm}^{2} \mathrm{~g}^{-1}\right)$. SLA is the measurement of the leaf thickness (Hodgson 1999). The SLA from the dumping pond sludge treatment showed the increased in soil fertility status. The increase in soil fertility was highly correlated to the increase in leaf area.

\section{GAS EXCHANGE PROPERTIES}

In this study, plant physiology was an important measure to identify the needs of maize growth, specifically the interaction between physicochemical needs with the treatments on the gas exchange variables, such as net photosynthesis $\left(\mathrm{A}_{\mathrm{net}}\right)$, stomata conductance $\left(\mathrm{G}_{\mathrm{s}}\right)$, internal $\mathrm{CO}_{2}$ concentration $\left(\mathrm{C}_{\mathrm{i}}\right)$ and transpiration rate $\left(\mathrm{E}_{\mathrm{L}}\right)$ and air vapour pressure deficit (D). The results of the gas exchange variables on $\mathrm{G}_{\mathrm{s}}$ and $\mathrm{E}_{\mathrm{L}}$ (stomata conductivity and transpiration), showed there was no significant differences relating to DP, MP, ANP, FP and ALP treatments, but there was significant difference with the Control

TABLE 4. Growth morphology of maize (Zea mays) grown in different POME sludges

\begin{tabular}{lcccccc}
\hline \multirow{2}{*}{ Parameter } & \multicolumn{5}{c}{ Treatment } \\
\cline { 2 - 7 } & Control & MP & ANP & FP & ALP & DP \\
\hline Leaf Area Ratio (LAR) & $13.11 \mathrm{a}$ & $9.95 \mathrm{a}$ & $11.42 \mathrm{a}$ & $12.46 \mathrm{a}$ & $14.83 \mathrm{a}$ & $16.19 \mathrm{a}$ \\
Specific Leaf Area (SLA) & $324.90 \mathrm{~b}$ & $424.80 \mathrm{ab}$ & $449.80 \mathrm{ab}$ & $505.3 \mathrm{ab}$ & $593.60 \mathrm{a}$ & $688.70 \mathrm{a}$ \\
Leaf Weigh Ratio (LWR) & $0.32 \mathrm{a}$ & $0.32 \mathrm{a}$ & $0.29 \mathrm{a}$ & $0.25 \mathrm{a}$ & $0.34 \mathrm{a}$ & $0.23 \mathrm{a}$ \\
Root Shoot Ratio (RSR) & $0.03 \mathrm{c}$ & $0.15 \mathrm{~b}$ & $0.12 \mathrm{~b}$ & $0.10 \mathrm{~b}$ & $0.09 \mathrm{~b}$ & $0.22 \mathrm{a}$ \\
\hline
\end{tabular}

Means with the same letter are not significantly different at $p \leq 0.05$, according to Tukey

TABLE 5. Effects of treatments on photosynthesis, stomata conductivity, intercellular carbon dioxide concentration and transpiration on maize

\begin{tabular}{lcccccc}
\hline \multirow{2}{*}{ Parameter } & \multicolumn{4}{c}{ Treatment } \\
\cline { 2 - 6 } & Control & MP & ANP & FP & ALP & DP \\
\hline $\mathrm{A}_{\text {net }}\left(\mu \mathrm{mol} \mathrm{CO} \square \mathrm{m}^{-2} \mathrm{~s}^{-1}\right)$ & $13.41 \mathrm{a}$ & $16.08 \mathrm{a}$ & $13.36 \mathrm{a}$ & $13.91 \mathrm{a}$ & $13.65 \mathrm{a}$ & $15.86 \mathrm{a}$ \\
$\mathrm{G}_{\mathrm{s}}\left(\mathrm{mol} \mathrm{H} \square \mathrm{O} \mathrm{m} \mathrm{s}^{-1}\right)$ & $0.07 \mathrm{~b}$ & $0.09 \mathrm{ab}$ & $0.09 \mathrm{ab}$ & $0.10 \mathrm{ab}$ & $0.11 \mathrm{ab}$ & $0.12 \mathrm{a}$ \\
$\mathrm{C}_{\mathrm{i}}\left(\mu \mathrm{mol} \mathrm{CO} \square \mathrm{mol}^{-1}\right)$ & $70.19 \mathrm{a}$ & $89.48 \mathrm{a}$ & $92.08 \mathrm{a}$ & $102.05 \mathrm{a}$ & $108.66 \mathrm{a}$ & $108.96 \mathrm{a}$ \\
$\mathrm{E}_{\mathrm{L}}\left(\mathrm{mmol} \mathrm{H} \square \mathrm{O} \mathrm{m}^{-2} \mathrm{~s}^{-1}\right)$ & $0.87 \mathrm{~b}$ & $0.95 \mathrm{ab}$ & $1.03 \mathrm{ab}$ & $1.04 \mathrm{ab}$ & $1.14 \mathrm{a}$ & $1.21 \mathrm{a}$ \\
$\mathrm{D}\left(\mu \mathrm{mol} \mathrm{CO} \square \mathrm{m}^{-2} \mathrm{~s}^{-1}\right)$ & $1.06 \mathrm{a}$ & $1.07 \mathrm{a}$ & $1.09 \mathrm{a}$ & $1.09 \mathrm{a}$ & $1.10 \mathrm{a}$ & $1.10 \mathrm{a}$ \\
\hline
\end{tabular}

Means with the same letter are not significantly different at $p \leq 0.05$, according to Tukey 
treatment $(p<0.05)$. However, there were no significant differences in net photosynthesis, intercellular carbon dioxide concentration, and air vapour pressure, for all the treatments. According to Nwoko et al. (2010) and Orhue et al. (2005), maize exhibited a positive growth response after the application of organic amendments. Referring to Khairudin et al. (2017), the DP treatment contains a large amount of organic matter due to the mature decomposition processes of POME sludge. Based on $\mathrm{C} / \mathrm{N}$ ratio analysis, POME sludge in DP treatment was identified as being more stable and having less microbial activity. The effectiveness of organic matter, especially $\mathrm{C}$ and $\mathrm{N}$, could help to improve the stomata conductance and transpiration process in the maize growth. Basically, plants regulate water loss through transpiration by opening and closing stomata (Volpe et al. 2011).

\section{THE RELATIONSHIP OF NET PHOTOSYNTHESIS ( $\left.\mathrm{A}_{\mathrm{NET}}\right)$ AND STOMATA CONDUCTIVITY $\left(\mathrm{G}_{\mathrm{s}}\right)$}

The linear regression analyses showed significant correlations between net photosynthesis (Pn) and stomata conductivity (Gs) for each treatment (Figure 2), namely ANP $\left(R^{2}=0.7058\right)$, FP $\left(R^{2}=0.7283\right)$, ALP $\left(R^{2}=0.7665\right)$ and $\left.\mathrm{DP}, \mathrm{R}^{2}=0.7875\right)$. The POME wastewater treatments (anaerobic, facultative, algae and dumping sludge) showed a positive effect on the maize growth. These applications could lead to stomata conductance in controlling the active intake of gas exchange in the atmosphere. Hazandy et al. (2011) reported that a positive linear relationship between photosynthesis $\left(\mathrm{A}_{\text {net }}\right)$ and stomata conductance $(\mathrm{Gs})$ was obviously related to the environment and leaf morphology. In addition, the correlation could be modulated in the long term with the growth conditions such as nitrogen,
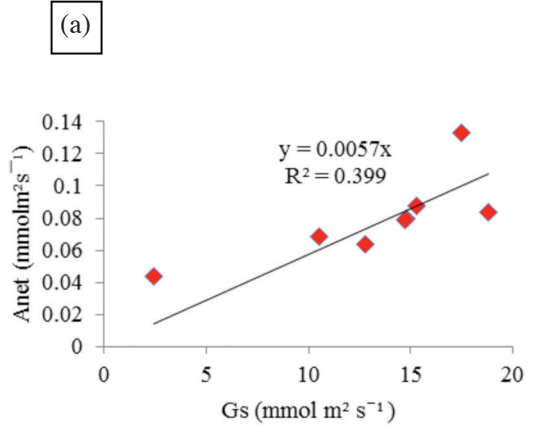

(c)

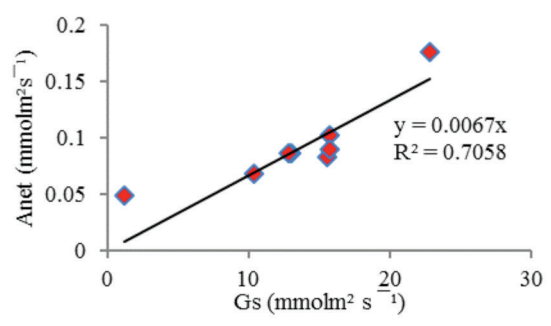

(e)

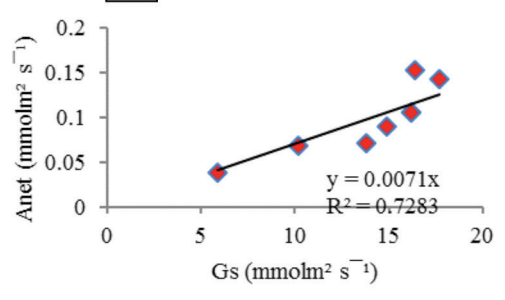

(b)

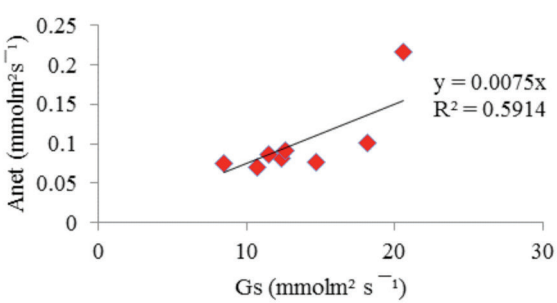

(d)

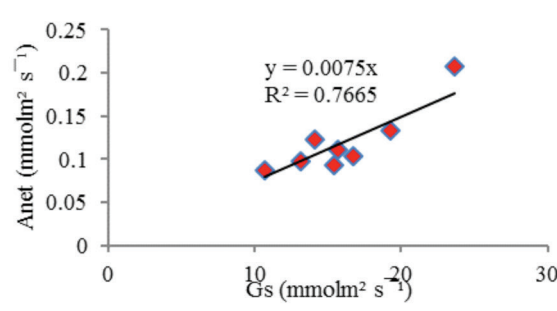

(f)

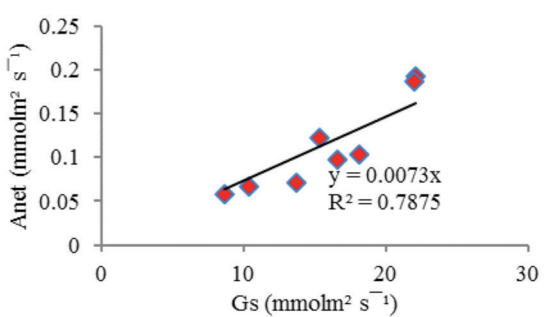

FIGURE 2. Correlation between net photosynthesis (Anet) and stomata conductance (Gs) for different treatments; Control (a), MP (b), ANP (c), FP (d), ALP (e) and DP (f) 
light environment, and high $\mathrm{CO}_{2}$ concentrations (Wong et al. 1979). The combination pattern of the stomataphotosynthesis model was the cause of the changes in physiological capacities of photosynthesis and patchy stomata closure (Uddling et al. 2005) and low leaf water potential (Hazandy et al. 2011; Kramer \& Boyer 1995). Furthermore, the abundance of CEC in the soil affected the stomata conductivity for the gas exchanges on the guard cells and epidermal turgor in the cell (Frank et al. 1997). Maize reacted and responded to the rising carbon dioxide concentration $\left(\mathrm{CO}_{2}\right)$ through increasing photosynthesis $\left(\mathrm{A}_{\text {net }}\right)$ and reduced stomata conductance $(\mathrm{Gs})$. The effects of elevated $\mathrm{CO}_{2}$ on plants and ecosystems are derived from two basic reactions (Long et al. 2004).

\section{CONCLUSION}

The POME sludge was safe to use for crop growth as proven by the results of the physicochemical analysis in this study. The heavy metal elements showed that $\mathrm{Cu}, \mathrm{Zn}$, and $\mathrm{Ni}$ were below the level of FAO/WHO standards that were identified as safe for human consumption. In this study, soil $\mathrm{pH}$ after the application of selected treatments (DP, ALP and FP) was measured as the optimum rate for plant establishment within the $\mathrm{pH}$ range 6 to 10. In conclusion, the POME sludge in the facultative (FP), algae (ALP) and dumping ponds (DP) had the potential to be used as organic amendments due to the positive effects on morphological and physiological characteristics of the plant performance.

\section{ACKNOWLEDGEMENTS}

The authors would like to thank Universiti Sultan Zainal Abidin (UniSZA), Universiti Putra Malaysia (UPM) and Universiti Teknologi MARA, Pahang for the facility assistance to conduct this project.

\section{REFERENCES}

Agrawal, A., Pandey, R.S. \& Sharma, B. 2010. Water pollution with special reference to pesticide contamination in India. Journal of Water Resource and Protection 2(05): 432-448.

Ali Huddin, I., Irvan, D., Mohd Nordin, A. \& Arezoo Fereidonian, D. 2012. Comparative study on characterization of Malaysian palm oil mill effluent. Research Journal of Chemical Sciences 2(12): 1-5.

Amanullah, M.J.H., Nawab, K. \& Ali, A. 2007. Response of specific leaf area (SLA), leaf area index (LAI) and leaf area ratio (LAR) of maize (Zea mays L.) to plant density, rate and timing of nitrogen application. World Applied Sciences Journal 2(3): 235-243.

American Public Health Association (APHA). 2005. Standard Methods for Examination Water and Wastewater. 20th ed. Washington D.C.: American Public Health Association.

Badiei, M., Jahim, J.M., Anuar, N. \& Abdullah, S.R.S. 2011. Effect of hydraulic retention time on biohydrogen production from palm oil mill effluent in anaerobic sequencing batch reactor. International Journal of Hydrogen Energy 36(10): 5912-5919.
Birch, C.J., Andrieu, B. \& Fournier, C. 2003. Dynamics of internode and stem elongation in three cultivars of maize. Agronomie 22: 511-524.

Brouwer, R. 1983. Functional equilibrium: Sense or nonsense? Netherlands Journal of Agricultural Science 31: 335-348.

Bruulsema, T.W., Witt, C., García, F., Li, S., Rao, T.N., Chen, F. \& Ivanova, S. 2008. A global framework for fertilizer BMPs. Better Crops 92(2): 13-15.

David, S. \& King, C. 2005. Improving Tree and Vine Growth with Compost. Organic Farming Systems Report. WA: Southern Metropolitan Regional Council and Organic Farming Systems.

Drinkwater, L.E., Wagoner, P. \& Sarrantonio, M. 1998. Legumebased cropping systems have reduced carbon and nitrogen losses. Nature 396(6708): 262-265.

Dungait, J.A., Hopkins, D.W., Gregory, A.S. \& Whitmore, A.P. 2012. Soil organic matter turnover is governed by accessibility not recalcitrance. Global Change Biology 18(6): 1781-1796.

Embrandiri, A., Singh, R.P. \& Ibrahim, M.H. 2013. Biochemical, morphological, and yield responses of lady's finger plants to varying ratios of plam oil mill waste (decanter cake) application as a bio-fertilizer. International Journal of Recycling of Organic Waste in Agriculture 2: 1-7.

Franks, P.J., Cowan, I.R. \& Farquhar, G.D. 1997. The apparent feedforward response of stomata to air vapour pressure deficit: Information revealed by different experimental procedures with two rainforest trees. Plant, Cell \& Environment 20(1): 142-145.

Gupta,A.K. \& Sinha, S. 2006. Chemical fractionation and heavy metal accumulation in the plant of Sesamum indicum (L.) var. T55 grown on soil amended with tannery sludge: Selection of single extractants. Chemosphere 64: 161-173.

Hazandy, A.H., Arifin, A., Mohd Kamil, I., Mohd Khairul Anuar, R., Abdul Latib, S. \& Wan Mohd Nazri, W.A.R. 2011. Gas exchange of three dipterocarp species in a reciprocal planting. Asian Journal of Plant Sciences 10(8): 408-413.

Hunt, R., Causton, D.R., Shipley, B. \& Askew, A.P. 2002. A modern tool for classical plant growth analysis. Annals of Botany 90(4): 485-488.

Hodgson, J.G., Wilson, P.J., Hunt, R., Grime, J.P. \& Thompson, K. 1999. Allocating CSR plant functional types: A soft approach to a hard problem. Oikos 85(2): 282-294.

Jensen, T.L. 2010. Soil pH and the availability of plant nutrients. IPNI Plant Nutrition TODAY. Fall 2010. No. 2. www.ipni. net/pnt.

Khairuddin, M.N., Isharudin, M.I., Abd Jamil, Z., Hamdan, J. \& Syahrizan, S. 2017. Shear strength and root length density analyses of entisols treated with palm oil mill effluent (POME) sludge. Soil \& Environment 36(2): 131-140.

Khairuddin, M.N., Zakaria, A.J., Isa, I.M., Jol, H., Rahman, W.M.N.W.A.\& Salleh, M.K.S. 2016. The potential of treated palm oil mill effluent (pome) sludge as an organic fertilizer. Journal of Agricultural Science 38(2): 142-154.

Kramer, P.J. \& Boyer, J.S. 1995. Water Relations of Plants and Soils. San Diego: Academic Press, Inc.

Kuhlman, H. 1990 Importance of the subsoil in the K nutrition of crops. Plant Soil 127: 129-136.

Kuzyakov, Y. \& Cheng, W. 2001. Photosynthesis controls of rhizosphere respiration and organic matter decomposition. Soil Biology and Biochemistry 33(14): 1915-1925.

Leita, L., De Nobili, M., Muhlbachova, G., Mondini, C., Marchiol, L. \& Zerbi, G. 1995. Bioavailability and effects 
of heavy metals on soil microbial biomass survival during laboratory incubation. Biology and Fertility of Soil 19(2-3): 103-108.

Long, S.P., Ainsworth, E.A., Rogers, A. \& Ort, D.R. 2004. Rising atmospheric carbon dioxide: Plants FACE the future. Annu. Rev. Plant Biol. 55: 591-628.

McCauley, A., Jones, C. \& Jacobsen, J. 2009. Soil pH and organic matter. Nutrient Management Module 8: 1-12.

Nwoko, C.O. \& Ogunyemi, S. 2010. Evaluation of palm oil mill effluent to maize (Zea mays L.) crop: Yields, tissue nutrient content and residual soil chemical properties. Australian Journal of Crop Science 4(1): 16-22.

Office Gene Technology Regulator- Australian Government (OGTR) 2008. The biology of Zea mays ssp (Maize). Australian Government Office of the Gene Technology Regulator.

Orhue, E.R., Osaigbovo, A.U. \& Vwioko, D.E. 2005. Growth of maize (Zea mays L.) and changes in some chemical properties of an ultisol amended with brewery effluent. African Journal of Biotechnology 4(9): 973-978.

Ryals, R., Kaiser, M., Torn, M.S., Berhe, A.A. \& Silver, W.L. 2014. Impacts of organic matter amendments on carbon and nitrogen dynamics in grassland soils. Soil Biology and Biochemistry 68: 52-61.

Sharma, J. \& Singh, R. 2001. Effect of nutrients supplementation on anaerobic sludge development and activity for treating distillery effluent. Bioresource Technology 79(2): 203-206.

SAS Institute Inc. 2007. SAS/STAT software, version 9, Cary, $\mathrm{NC}$, USASAS Institute, Inc.

Silva, J.D.C., Leal, T.T.B., Araújo, A.S.F., Araujo, R.M., Gomes, R.L.F., Melo, W.J. \& Singh, R.P. 2010. Effect of different tannery sludge compost amendment rates on growth, biomass accumulation and yield responses of capsicum plants. Waste Management 30: 976-1980.

Silva, M.D., Ferreira Araújo, A.S., Pinheiro Leal Nunes, L.A., de Melo, W.J. \& Pratap Singh, R. 2013. Heavy metals in cowpea (Vigna unguiculata L.) after tannery sludge compost amendment. Chilean Journal of Agricultural Research 73(3): 282-287.

Rumpel, C., Crème, A., Ngo, P.T., Velásquez, G., Mora, M.L. \& Chabbi, A. 2015. The impact of grassland management on biogeochemical cycles involving carbon, nitrogen and phosphorus. Journal of Soil Science and Plant Nutrition 15(2): 353-371.

Ryals, R., Kaiser, M., Torn, M.S., Berhe, A.A. \& Silver, W.L. 2014. Impacts of organic matter amendments on carbon and nitrogen dynamics in grassland soils. Soil Biology \& Biochemistry 68: 52-61.

Taiz, L. \& Zeiger, E. 1991. Plant Physiology: Mineral Nutrition. Redwood City: The Benjamin Cummings Publishing Co. Inc. pp. 100-119.
Tisdale, S.L., Nelson, W.L., Beaton, J.D. \& Havlin, J.L. 1993. Soil Fertility and Fertilizers. 5th ed. New York: Macmillan Publishing Company.

Uddling, J.,Hall, M., Wallin, G. \& Karlsson, P.E. 2005. Measuring and modelling stomatal conductance and photosynthesis in mature birch in Sweden. Agricultural and Forest Meteorology 132(1): 115-131.

Volpe, V., Manzoni, S., Marani, M. \& Katul, G. 2011. Leaf conductance and carbon gain under salt-stressed conditions. Journal of Geophysical Research: Biogeosciences 116(G4).

Wong, S.C., Cowan, I.R. \& Farquhar, G.D. 1979. Stomatal conductance correlates with photosynthetic capacity. Nature 282: 424-426.

Zeng, F., Ali, S., Zhang, H., Ouyang, Y., Qiu, B., Wu, F. \& Zhang, G. 2011. The influence of $\mathrm{pH}$ and organic matter content in paddy soil on heavy metal availability and their uptake by rice plants. Environmental Pollution 159(1): 84-91.

Zhong, W., Gu, T., Wang, W., Zhang, B., Lin, X., Huang, Q. \& Shen, W. 2010. The effects of mineral fertilizer and organic manure on soil microbial community and diversity. Plant and Soil 326(1-2): 511-522.

Mohd Nizar, K. \& Abd Jamil, Z.

Institute of Agrobiotechnology

Universiti Sultan Zainal Abidin, Campus Tembila

22200 Besut, Terengganu Darul Iman

Malaysia

Isharudin, M.I.*

Department of Land Management

Faculty of Agriculture

Universiti Putra Malaysia

43400 UPM Serdang, Selangor Darul Ehsan

Malaysia

Hazandy, A.H.

Institute of Tropical Forestry and Forest Products (INTROP)

Universiti Putra Malaysia

43400 UPM Serdang, Selangor Darul Ehsan

Malaysia

*Corresponding author; email: imi@upm.edu.my

Received: 22 June 2017

Accepted: 19 December 2017 